\title{
AZ AGRÁR- ÉS VIDÉKFEJLESZTÉSI TÁMOGATÁSBAN RÉSZESÜLŐ CSALÁDOK SZOCIODEMOGRÁFIAI ÉS GAZDÁLKODÁSI SAJÁTOSSÁGAI EGY DÉL-ALFÖLDI PÉLDÁN KERESZTÜL
}

\author{
SOCIO-DEMOGRAPHIC AND FARMING \\ CHARACTERISTICS OF FAMILIES RECEIVING \\ AGRICULTURAL AND RURAL DEVELOPMENT \\ SUBSIDIES THROUGH AN EXAMPLE FROM THE \\ SOUTHERN GREAT PLAIN
}

\author{
Horváth Péter ${ }^{1}$ \\ ${ }^{1}$ Vidékfejlesztési és Regionális Gazdaságtan Tanszék, Gazdaságtudományi Kar, Debreceni Egyetem
}

\author{
Kulcsszavak: \\ EU támogatás \\ mezőgazdaság \\ vidékfejlesztés \\ Dél-alföldi Régió \\ szociodemográfia \\ Keywords: \\ EU subsidy \\ agriculture \\ rural development \\ Southern Great Plain Region \\ sociodemography
}

\section{Összefoglalás}

A rendszerváltás jelentős változásokat eredményezett a hazai vidék életében, míg korábban a hazai vidéki jövedelmek világszínvonalúak voltak, addig a rendszerváltás után sereghajtókká váltunk. Az európai uniós csatlakozás és az európai vidéki politika új megvilágításba helyezte a vidéki területeket és az itt élő lakosságot. A tanulmányban a csatlakozás után 15 évvel kerül bemutatásra, hogy milyen szociodemográfiai és gazdálkodási ismérvek jellemzik az európai uniós támogatásban részesülő családokat a Dél-alföldi Régióban.

Abstract

The change of The change of regime resulted in significant changes in the life of the Hungarian rural areas; while the rural income of Hungary used to be world-class, after the change of regime it became incredibly low. Accession to the European Union and the European rural policy opened new aspects for rural areas and the people living there. The study presents the sociodemographic and farming characteristics of families receiving $E U$ subsidies in the Southern Great Plain Region 15 years after the EU accession.

1 Kapcsolattartó szerző. Tel.: +36 52508444

E-mail cím: horvath.peter@econ.unideb.hu 


\section{Bevezetés}

A mezőgazdaság már a rendszerváltás előtt is a vidék felemelkedését szolgálta. A mezőgazdasági nagyüzem „hátán vitte” a vidéket, amely egyebek mellett a foglalkoztatásban, a javuló és felzárkózó jövedelemben, és a nagyüzem által ellátott széleskörü közfeladatokban merült ki. A hivatalos munkaidő mellett megteremtette a mezőgazdasági dolgozók vállalkozásának a lehetőségét a maszekoláson keresztül és a háztáji integráció révén jelentős szerepet kapott a vidéki emberek önellátásában, illetve árutermelésében. Ezek a tényezők együttes hatása általános biztonságérzetet keltett a vidéki lakosságban, hiszen a jövedelmük kiszámítható, munkahelyük biztosítva volt. A rendszerváltást követően gyökeresen megváltozott a mezőgazdaság és vidék kapcsolata, aminek következtében a mezőgazdaságban foglalkoztatott vidéki lakosság a rendszerváltás egyik legnagyobb vesztesévé vált [9].

A mezőgazdaságban foglalkoztatottak száma 1988 után jelentősen lecsökkent, a KSH adatai alapján 239400 fő volt 2003-ban. 2007-es adatok alapján a KSH 90 ezer főben adja meg a mezőgazdasági szervezeteknél alkalmazottak számát [7], míg más helyen 194000 fő szerepel mezőgazdasági alkalmazottként [6]. Egy kutatás alapján azonban megállapítható, hogy magyar felnőtt népesség 61,5\%-a közvetve vagy közvetlenül agrárérintett [5].

A rendszerváltás hozadéka, hogy a vidék elvesztette addigi mezőgazdasági nagyüzemre támaszkodó bázisát és magára maradt. Több kistelepülésen, főleg Észak-Magyarországon, illetve a Dél-dunántúli területeken részén óriási volt az elvándorlás, a falvak elnéptelenedése volt jellemző, amely nagymértékben állt összefüggésben azzal, hogy a mezőgazdaságnak jelentősen csökkent az eltartóképessége, sokkal kevesebb embert foglalkoztat ma a mezőgazdaság, mint a 80-as, 90-es években, ami rendkívül aggasztó egy ilyen kifejezetten jó mezőgazdasági adottságú országban, mint amilyen Magyarország. Ezért kiemelt feladatunk az, hogy a birtokstruktúra megváltoztatásával és a hozzá rendelt támogatási rendszer megváltoztatásával elérjük azt, hogy minél több ember éljen mezőgazdaságból, annak érdekében, hogy a vidék eltartóképessége megmaradjon, és ne kelljen elvándorolni az embereknek [2]. Ez az állapot az európai uniós csatlakozással megváltozott, amikortól is ismételten egymástól elválaszthatatlan fogalompárként jelent meg az agrárgazdaság és vidékfejlesztés [8].

2001-ben a Göteborgi csúcstalálkozó eredményeképpen megszületett Magyarország európai uniós csatlakozásának céldátuma, amelynek révén 2004-től EU tagállammá vált hazánk. Az uniós csatlakozás azonban nem hozta el a várva várt hatást, hiszen a csatlakozó tíz ország közül pozíció vesztesként, sereghajtóként léphettünk be a Közösségbe. A gazdasági egyensúlyra és versenyképességre vonatkozó mutatók árnyalt képet mutattak [1]. Más szerzők szintén megállapítják, hogy nem történtek alapvető változások a magyar agrárgazdaságban a csatlakozás után, bizonyos mutatók tekintetében romlott a helyzet, úgymint a foglalkoztatottság, bruttó hozzáadott érték előállítás, beruházások mezőgazdasági részaránya [3].

\section{A kutatás módszertana}

A személyes (face to face) zárt kérdőíves interjúkon alapuló felmérés egy konkrét délalföldi járás szintjén vizsgálta az agrár- és vidékfejlesztési támogatások gyakorlatát, de a levonható tanulságok akár országos szinten is jellemzőek lehetnek.

A kutatás helyszínéül szolgáló járás 11 településnek mindegyikéről rendelkezésemre állt a Magyar Államkincstár 2018. évi támogatási adatbázisa. Ez alapján 1.080 családot érintettek a támogatások. A család szó itt azért hangsúlyos, mert az adatbázisban azonos lakcím alatt több név is szerepelt, illetve voltak olyan nevek, amelyek az adatsorban többször ismétlődtek (azaz többféle támogatást vettek igénybe). A nevek és a lakcímek ismétlődéseinek a kiszűrése után került sor az adatfelvétel lebonyolítására, egyszerű véletlen (valószínűségi) mintavételi technika alkalmazásával. Az alapsokaságból (azaz az 1.080 érintett háztartásból) végül 293 válaszadó került a mintába, ami 27 százalékos elérést jelent. A véletlen minta, tehát kielégítően pontosan reprezentálja a konkrét dél-alföldi járásban támogatásban részesülők összességét (a maximális becslési bizonytalanság itt kisebb, mint 5\%), de a kapott eredmények országos vagy akárcsak megyei szintre való kivetítésénél óvatosan kell eljárni, hiszen a támogatási 
gyakorlatok nagyon eltérőek lehetnek regionálisan vagy akár egyetlen régió különböző járásaiban is. Ugyanakkor a válaszok elemzése során feltárt szignifikáns belső összefüggések szinte bizonyosan általánosan is érvényesek, még akkor is, ha az alapbecsléseknél könnyen elképzelhető, hogy ezek eloszlása eltérő lehet földrajzilag. Éppen ezért, ahol csak lehetett és értelmes is volt, igyekeztem ezeket a belső összefüggéseket feltárni.

A 293 fős mintába belekerült 3 nagygazdaság is, melyekben 23 főnél több embert foglalkoztatnak és nagyon sok állatott tartanak, illetve nagyon nagy területen folytatnak növénytermelést. E gazdaságok jellemzői természetesen nagyon megnövelik a válaszok szórását, és így csökkentik a becslések megbízhatóságát. Ezért úgy döntöttem, hogy ezt a 3 nagyvállalkozást kihagyom az adatok elemzéséből, így a kutatás esetszáma: N=290 mikro-, kisés közepes mezőgazdasági gazdálkodó.

Az adatfelvételre 2019 tavaszán került sor, tehát olyan időszakban, amikor a válaszadók (minden családnál a támogatást elnyerő és a gazdaságot vezető személy) még pontosan emlékeztek az előző év gazdálkodására, és ezen belül az elnyert támogatásokra is. A nominális, illetve ordinális skálán mért adatok összefüggés-vizsgálata kereszttábla segítségével történt. A kontingencia-táblázat (kereszttábla) két változó közötti kapcsolatot vizsgálja, ahol a táblázat sorai egy változó értékeihez, míg oszlopai egy másik változó értékeihez tartoznak. A táblázat egy eleme a megfelelő sor, illetve oszlopváltozó együttes előfordulási gyakoriságát jelenti a mintában. Továbbá a leíró statisztikai elemzések során egyszempontos varianciaanalízist alkalmaztam, amely két vagy több minta átlagának az összehasonlítására szolgál az F-eloszlás használatával, illetve t-próbát használtam az átlagok közötti különbözőség vizsgálatára [4].

\section{A gazdaság vezetőjére vonatkozó információk}

A támogatott agrárgazdaságok 70 százalékánál férfi válaszolt a kérdésekre, és ez azt is jelzi, hogy a járás agrárvállalkozásaiban hagyományosan férfiuralom van, hiszen mindenütt az elsőszámú döntéshozó volt a válaszadó. Az is a régi patriarchális hagyományok tovább élesét jelzi, hogy mindössze a válaszadók 13 százaléka 40 évnél fiatalabb, miközben 39 százalékuk 60 évnél idősebb. Összeségében az derült ki, hogy a járás támogatásban részesült agrárvállalkozásainak felét 50 évnél idősebb férfi vezeti, ötödét 50 évnél fiatalabb férfi, másik ötödét (18\%) pedig 50 évnél idősebb nő. Ugyanakkor, azért a vállalkozások tizedében 50 évnél fiatalabb nők kerültek döntéshozói szerepbe (1. ábra).

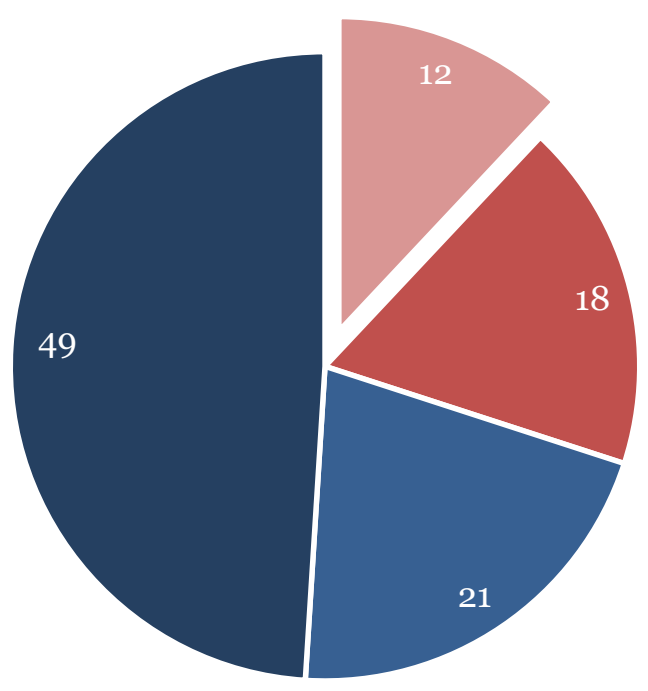

- 50 évnél fiatabb nő

- 50 évnél idősebb nő

- 50 évnél fiatalabb férfi

- 50 évnél idősebb férfi

1. ábra: A támogatásban részesült agrárvállalkozások döntéshozói

Forrás: saját kutatás 
A támogatásban részesülő agrárvállalkozások vezetőinek negyede főfoglalkozású termelő, háromnegyedük viszont mellékfoglalkozásként végzi a mezőgazdasági termelést. A férfiak körében valamivel magasabb főfoglalkozásúak aránya, mint a nők körében (Chinégyzet $=3,00 ; \mathrm{df}=1$, egyoldalú hipotézisvizsgálat: $\mathrm{p}=0,05$ ) (2. ábra).

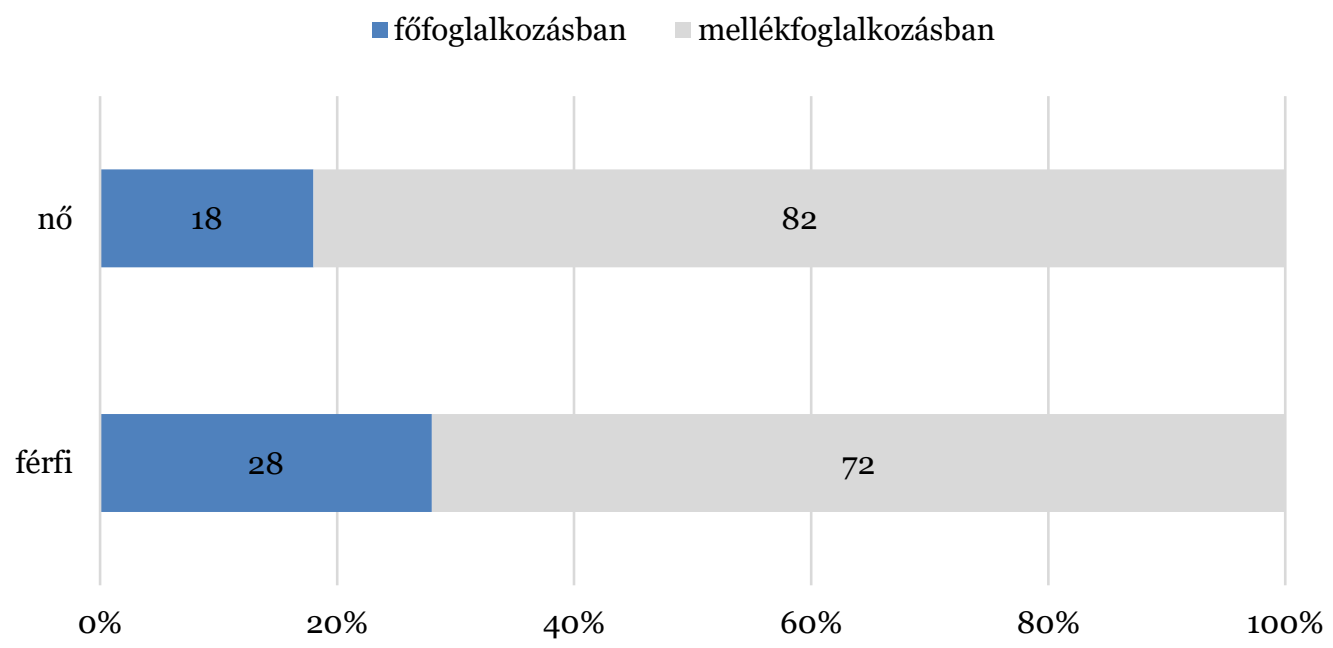

Forrás: saját kutatás

2. ábra: A mezőgazdasági tevékenység végzése nemek szerint

Életkori csoportok szerint nézve nem találtunk szignifikáns eltéréseket a fó/mellékfoglalkozás arányokban, de tendencia jelzésként figyelemreméltó, hogy a főfoglalkozásúak aránya az 50-59 évesek körében a legmagasabb (31\%) és a 6o évnél idősebbek körében a legalacsonyabb (18\%). Itt nyilván arról van szó, hogy számottevően sokan nyugdíjba menetelük után vágtak bele mellékfoglalkozásként (azaz nyugdíjkiegészítő tevékenységként) az agrárvállalkozásba. Az persze szinte teljesen bizonyos, hogy ők nyugdíjba menés előtt is foglalkoztak valamilyen és valamekkora volumenú háztáji jellegü mezőgazdasági tevékenységgel.

Az agrártámogatást kapó vállalkozók 87 százaléka őstermelőként, 6 százalékuk egyéni vállalkozóként, 7 százalékuk pedig egyéb formában (pl. családi gazdaság, szövetkezet vagy Bt. tagjaként) végzi a mezőgazdasági tevékenységét.

A válaszadók 5 százaléka kevesebb, mint 8 általános iskolai osztály végzettséggel rendelkezik, 13 százalékuk pedig befejezte az általános iskolát, de nem tanult tovább. Szakmunkás végzettséggel a támogatásban részesülő agrárvállalkozók 31 százaléka, szakközépiskolai végzettséggel pedig 17 százalékuk rendelkezik. Gimnáziumi érettségije szintén 17 százalékuknak van, felsőfokú végzettsége pedig csak 16 százalékuknak (BSc szintü=11\%, MSc szintü=5\%).

Elnagyoltabban nézve: nincs érettségije $=49 \%$, érettségizett $=35 \%$, diplomás $=16 \%$. A 18 29 évesek körében azonban $42 \%$ a diplomások aránya, azaz a vizsgált járásban is egyre több a diplomás agrárértelmiségi (Chi-négyzet $=42,78, \mathrm{df}=6, \mathrm{p}<0,0001$ ) (3. ábra). 


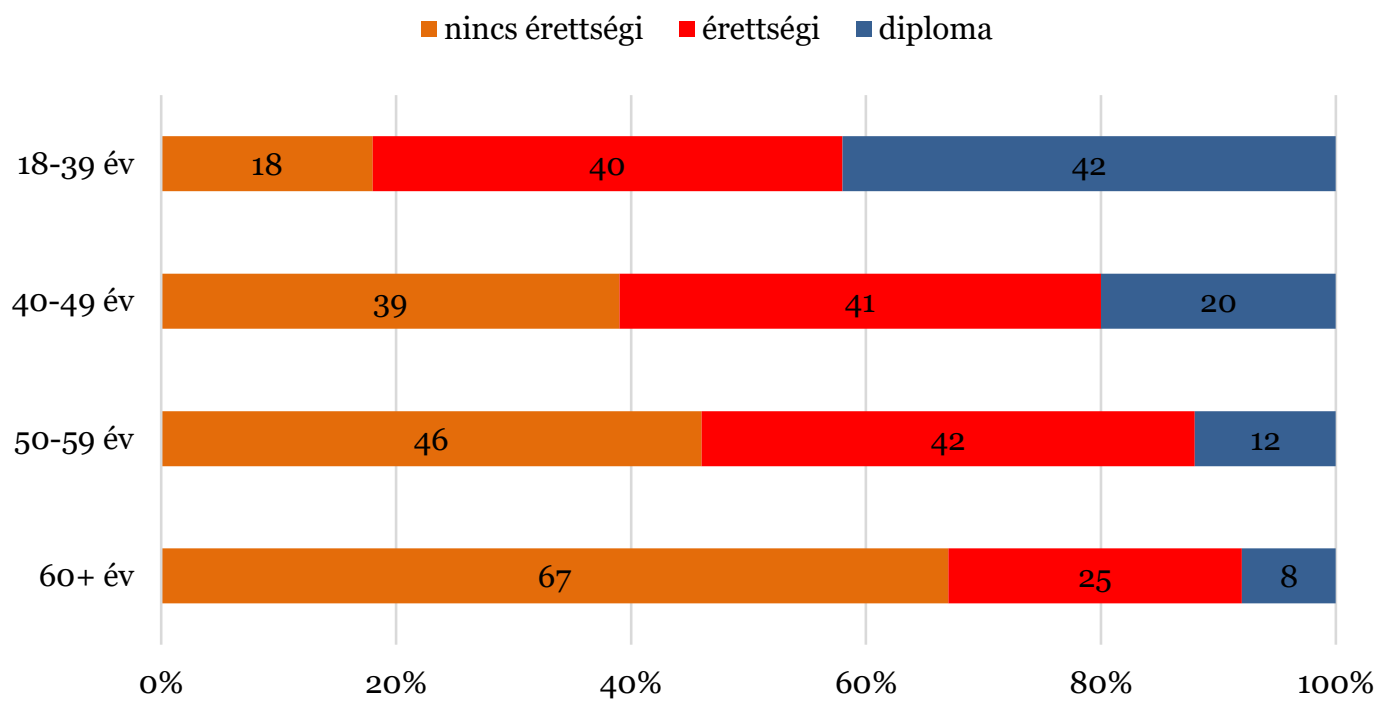

3. ábra: Iskolázottsági szintek életkori csoportok szerint

Forrás: saját kutatás

$\mathrm{Az}$ életkoron túl nemek szerint is szignifikáns az iskolázottsági szintek eloszlásának különbsége (Chi-négyzet $=11,56 \mathrm{df}=2, \mathrm{p}=0,003$ ) (4. ábra).

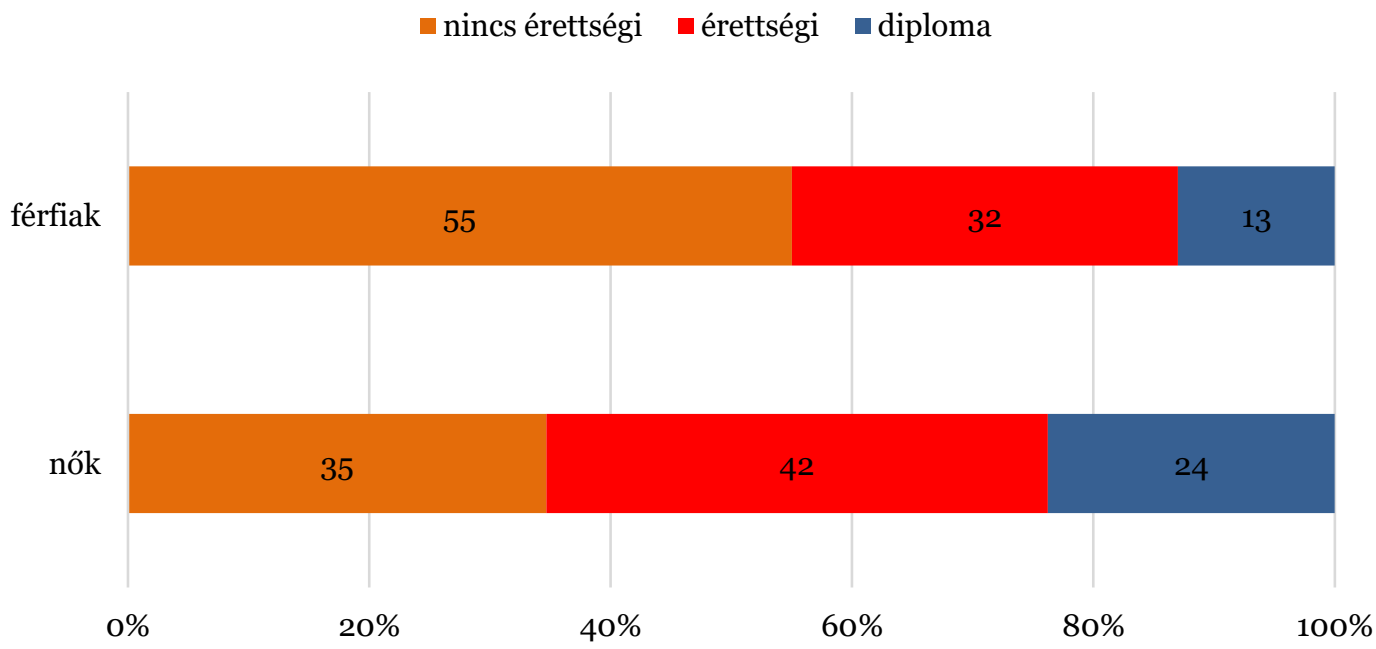

Forrás: saját kutatás

4. ábra: Iskolázottsági szintek nemek szerint

Speciális mezőgazdasági végzettsége a támogatásban részesülők kétharmadának van, az esetek 37 százalékában ez aranykalászos gazda minősítést jelent, az esetek 26 százalékában viszont felsőfokú mezőgazdasági végzettséget (szakközépiskolai végzettség $=\mathbf{2 8 \%}$, alapszintű végzettség $=9 \%$ ).

A támogatásban részesülők 88 százaléka több mint 5 éve foglalkozik mezőgazdasági tevékenységgel, tizedük pedig 1-5 éve, azaz a támogatott vállalkozások vezetőinek mindössze 2 százaléka tekinthető kezdőnek az agrárgazdaságban. A 18-39 évesek körében azonban 37\% azok aránya, akik 5 évnél rövidebb ideje foglalkoznak mezőgazdasággal, míg a 60 évnél idősebbek körében csak $3 \%$ ez az arány (Chi-négyzet $=35,22, \mathrm{df}=3, \mathrm{p}<0,0001$ ). Tehát van az úgy, hogy nyugdíj után kezdőként vág bele valaki a mezőgazdasági tevékenységbe, de azért ez ritka jelenség. 
A leginkább figyelemreméltó eredmény itt az, hogy iskolai végzettség szerint nézve is erősen szignifikánsak a különbségek (Chi-négyzet $=11,01, \mathrm{df}=2, \mathrm{p}=0,004$ ). Az érettségi nélküliek körében $6 \%$ azok aránya, akik 5 évnél rövidebb ideje foglalkoznak mezőgazdasággal, a diplomások körében viszont $23 \%$ ugyanez az arány, és az iskolázottság hatása akkor is szignifikáns, ha az összefüggés rendszerből kiszürjük az életkori hatást. Megállapítható tehát, hogy a képzetlen gazdákat a rutin, a képzetteket viszont a tanulással szerzett tudás segíti hozzá az agrártámogatás elnyeréséhez (5. ábra).

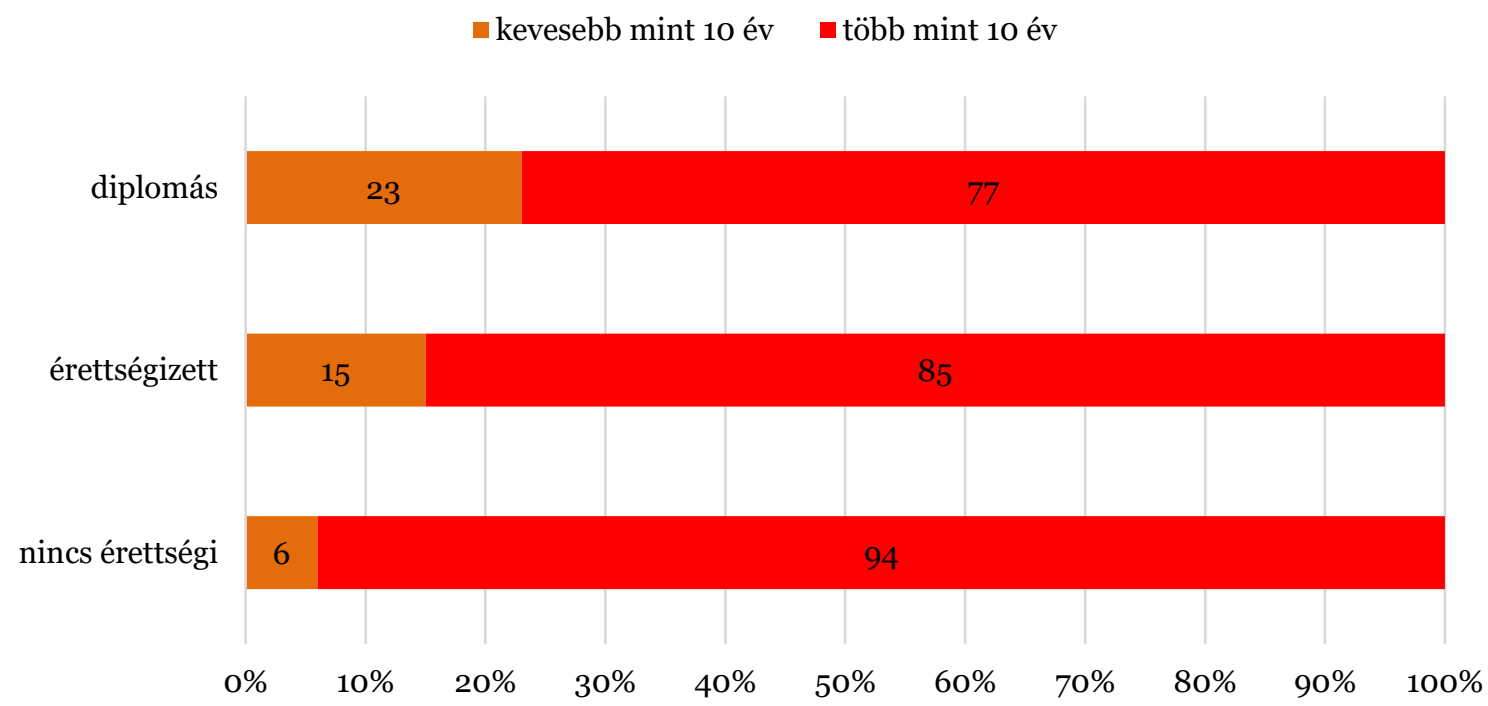

5. ábra: Mezőgazdasági tevékenységgel való foglalkozás iskolázottság szerint Forrás: saját kutatás

\section{A gazdaságra vonatkozó információk}

A vizsgált agrárvállalkozások 83 százaléka csak növénytermesztéssel foglalkozik, 15 százalékuk a növénytermesztés mellett állattenyésztéssel is, 2 százalékuk pedig növénytermesztés mellett erdőgazdálkodással is.

A földek minőségét jelző átlagos aranykorona értékek átlaga=19,1 AK/ha (szórás=4,7) azonban elmarad az országos átlagtól $(=21,8 \mathrm{AK} / \mathrm{ha})$. A járás támogatásban részesülő gazdaságainak 5 százalékánál az átlagos aranykorona érték kisebb, mint 10 AK/ha, ők tehát kifejezetten rossz földeken gazdálkodnak. A gazdaságok további 37 százalékánál az átlag 11 és 19,5 AK/ha érték közé esik, tehát a helyi átlagnál számottevően gyengébb minőségű a föld.

Az átlagos aranykorona értékek módusza és mediánja $20 \mathrm{AK} / \mathrm{ha}$ a járásban, és ez az érték a gazdaságok 24 százalékát jellemzi. A helyi átlagnál számottevően jobb minőségü földeken ( $x>20 \mathrm{AK} / \mathrm{ha})$ a válaszadók 34 százaléka gazdálkodik, az országos átlagnál is jobb minőségü földeken ( $\mathrm{x}>22,5 \mathrm{AK} / \mathrm{ha}$ ) azonban csak 12 százalékuk.

A járásban 25,6 2,8 ha az átlagos birtokméret. Az alsó negyed határa 4 ha, a felső negyedé pedig 22 ha. Saját tulajdonú földön a válaszadók 88 százaléka gazdálkodik (átlagos terület $=17,5 \pm 2 \mathrm{ha}$ ). Bérelt területen is gazdálkodik a válaszadók 42 százaléka (átlagos terület $=23,3 \pm 3,6 \mathrm{ha})$.

A legtöbb válaszadónak (93\%) szántóföldje is van (átlagos terület=23,7 $\pm 2,7 \mathrm{ha}$ ). Halastója, nádasa, szőlője és gyümölcsöse viszont gyakorlatilag senkinek sincs a járásban (1. táblázat). 
1. táblázat: A földhasználat alakulása a járásban

Földhasználat a járásban

van\% átlagosan (ha) $\quad \pm$ (ha)

\begin{tabular}{|c|c|c|c|}
\hline saját föld & $88 \%$ & 17,5 & 2,0 \\
\hline bérelt föld & $42 \%$ & 23,3 & 3,6 \\
\hline összesen & $100 \%$ & 25,6 & 2,8 \\
\hline ebből & van\% & átlagosan (ha) & \pm (ha) \\
\hline szántó & $93 \%$ & 23,6 & 2,7 \\
\hline gyep & $21 \%$ & 13,1 & 2,8 \\
\hline erdő & $6 \%$ & 4,1 & 1,3 \\
\hline kert & $2 \%$ & 1,6 & 0,4 \\
\hline kedvezőtlen adottságú terület & $7 \%$ & 39,2 & 10,1 \\
\hline NATURA 20oo & $5 \%$ & 37,3 & 9,6 \\
\hline AKG (Agrár környezetgazdálkodás) & $3 \%$ & 49,8 & 14,0 \\
\hline múvelés alól kivett terület & $2 \%$ & 2,9 & 1,2 \\
\hline
\end{tabular}

Forrás: Saját kutatás

A járásban az árpa a leggyakrabban termelt szántóföldi növény. Gyakorlatilag mindenki foglalkozik árpatermesztéssel. A kukorica esetében viszont nagyobb a termelésbe vont földterületek átlaga, mint az árpa és a búza esetében. Napraforgó termeléssel a gazdák 1 százaléka foglalkozik, repcét viszont senki se termelt 2019-ben (2. táblázat).

2. táblázat: Szántóföldi növénytermesztés a járásban (legfontosabb növények)

\begin{tabular}{l|c|c|c} 
& \multicolumn{1}{c}{ termelők\% } & $\begin{array}{c}\text { terület } \\
\text { átlag (ha) }\end{array}$ & $\begin{array}{c}\text { hozam } \\
\text { átlag (t/ha) }\end{array}$ \\
\hline árpa & $94 \%$ & 10,0 & 4,0 \\
\hline búza & $58 \%$ & 11,3 & 4,2 \\
\hline kukorica & $31 \%$ & 15,4 & 3,0 \\
\hline silókukorica & $11 \%$ & 9,6 & 4,4 \\
\hline
\end{tabular}

Forrás: saját kutatás

Sertés tartással a gazdaságok 29 százalékában foglalkoznak, de a sertéstartók harmada 10 darabnál kevesebb állatot tart. 50 darabnál nagyobb volumenú sertéstartással csak a sertéstartó gazdaságok 15 százaléka foglalkozik.

Szarvasmarhát a gazdaságok 9 százalékában tartanak: 46 százalékuknál 10 darabnál, 27 százalékuknál pedig 50 darabnál kisebb az állomány. A szarvasmarhatartással foglakozó gazdaság 23 százaléka viszont 50- vagy több állatot tart.

Juh tartás a gazdaságok 5 százalékában fordul elő: 3 gazdaságba 1-3 juhot tartanak, 9 gazdaságban 10-30 állatból áll az állomány, és van egy gazdaság, ahol 150 darabból áll a nyáj.

A gazdaságok 45 százalékában van egy (34\%) vagy több (11\%) traktor. A traktorok

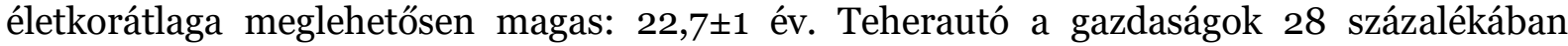
található: $1 \mathrm{db}=9 \%$, több is $19 \%$. A járásban a teherautó állomány is erősen elöregedett: életkorátlag $=18,1 \pm 1$ év.

Valamilyen mezőgazdasági termelőtevékenység mellett végzett más termelő vagy szolgáltató tevékenységgel, mindössze 4 család foglalkozik a 290-ből (falusi turizmus, vadászati turizmus, kézműves tevékenység, tájgondozás (2)). 
Az gazdasági szakemberek azt szokták mondani, hogy amelyik gazdaság nem növekszik, az zsugorodni fog. Ehhez képest a járás támogatott gazdaságainak 69 százalékában a szinten tartás a gazdálkodási terv. A bővítést $23 \%$ tervezi, miközben $8 \%$ csökkenteni szeretné a gazdaságát.

A támogatott családok 7 százalékában 30 ezer forint alatt van az 1 före jutó havi jövedelem, 20 százalékuknál ez 30-50 ezer forint, 32 százalékuknál 50-70 ezer forint, 26 százalékuknál 70-100 ezer forint, 10 százalékuknál 100-150 ezer forint, végül 5 százalékuknál

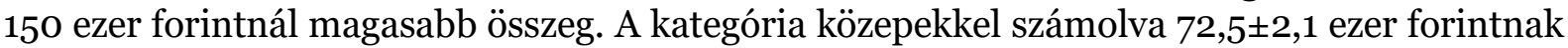
adódik az átlag.

Azok körében viszont, akik a gazdaságuk csökkentését tervezik mindössze 54 ezer forint az átlag, míg a szinten tartást és a növekedést tervezők körében 74 ezer forint. Ez tehát azt jelzi, hogy a szegénység egyáltalán nem ösztönzi növekedési tervek kovácsolására a járásban élő gazdákat, sốt inkább arra hajlamosítja őket, hogy feladják $(\mathrm{F}=3,44, \mathrm{df}=2$ és 286, p=0,033).

Azt, hogy: „a család megélhetési gondokkal küzd” a válaszadók 7 százaléka érezte jellemzőnek a saját családjára. Azt viszont 60 százalékuk, hogy: „a család alapvető igényeit ki tudja elégíteni, de a nem tervezett kiadások hatalmas terheket okoznak". A válaszadók 31 százaléka azzal a válaszlehetőséggel értett egyet, hogy: „a család az alapvető igények kielégítésén túl félre tud tenni és tartalékokkal rendelkezik”. Ugyanakkor csak 1\% gondolja azt, hogy: „a család olyan mértékü tartalékokkal rendelkezik, amely akár hosszú távon is biztosítani tudná a megélhetést/alapvető igények kielégítését”.

Ezek az önbesorolások természetesen erősen függenek az egy före jutó havi jövedelmektől. Ha összevonjuk a ritkán előforduló szélső értéket a hozzájuk közel eső (viszonylag) gyakori értékekkel, akkor azt mondhatjuk: a válaszadók 67 százaléka inkább elégedetlen családja anyagi helyzetével, 33 százalékuk viszont inkább elégedett. Az inkább elégedetlenek körében 61 ezer forint az egy főre jutó havi jövedelmek átlaga, míg az inkább elégedettek körében 95 ezer forint $(\mathrm{t}=7,9, \mathrm{df}=145, \mathrm{p}<0,0001)$. Mindezek után nem meglepő, hogy az anyagi helyzet megítélése erősen hat a gazdálkodással kapcsolatos tervekre is.

$\mathrm{Az}$ adatokból egyértelműen az derült ki, az anyagi helyzettel való elégedettség, és a megtakarítások léte jelentősen növeli a bővítési tervek valószínűségét. Ez nem túl meglepő. Az viszont igen, hogy a megtakarítások hiánya és az elégedetlenség, nem a szinten tartási tervek valószínüségét növeli, hanem a csökkentési tervekét (6. ábra).

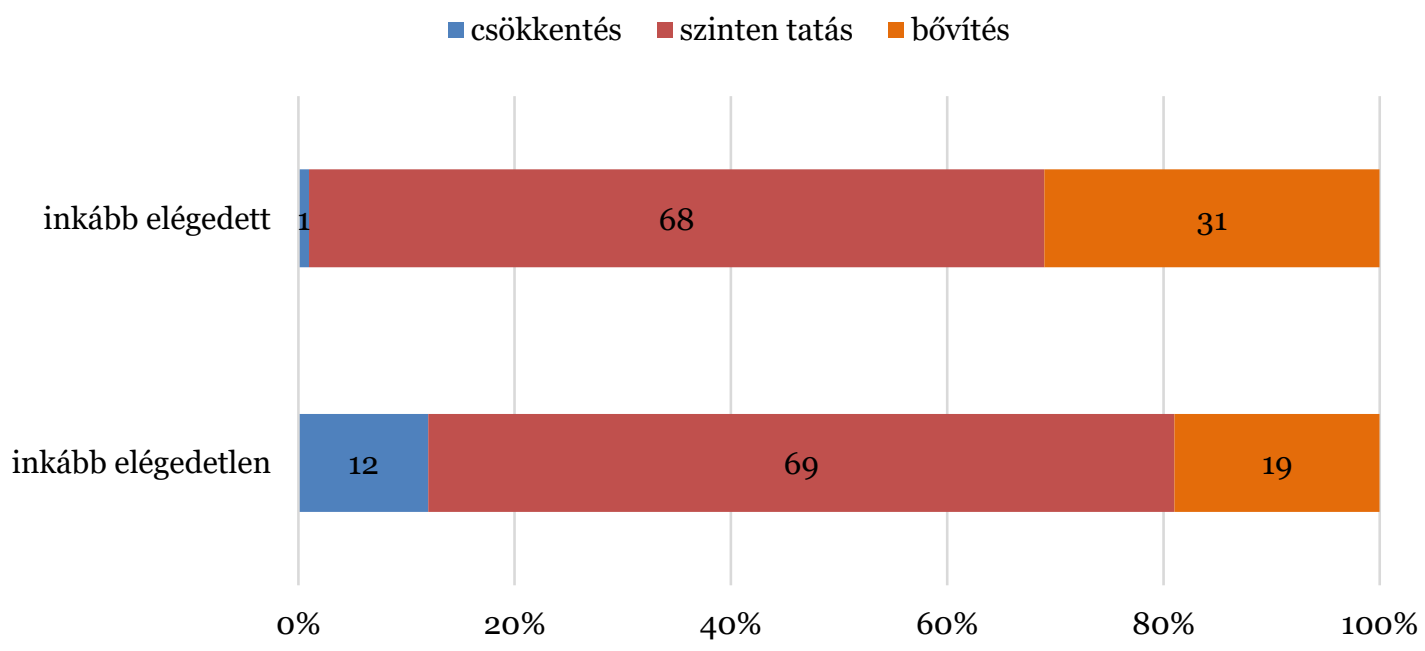

6. ábra: Gazdálkodási tervek a család anyagi helyzetének megítélése szerint Forrás: saját kutatás

A családok 96 százalékának van gazdaságból, gazdálkodásból származó jövedelme, miközben munkabér jövedelemmel csak 47 százalékuk rendelkezik. Kizárólag munkajövedelemre azonban csak a családok 2 százaléka támaszkodik, míg kizárólag gazdaságból/gazdálkodásból származó jövedelemre a tizedük (3. táblázat). 
3. táblázat: A családok bevételi forrásainak százalékos aránya

$\begin{array}{llll}\text { Forrás } & \text { van\% } & 100 \% & \text { átlag\% }\end{array}$

\begin{tabular}{|c|c|c|c|}
\hline gazdaságból/gazdálkodásból származó & 96 & 10 & 40 \\
\hline $\begin{array}{c}\text { jövedelem } \\
\text { munkabér }\end{array}$ & 47 & 2 & 29 \\
\hline nyugdíj & 44 & 1 & 27 \\
\hline családi pótlék & 12 & 0 & 1 \\
\hline jövedelempótló juttatás & 3 & 0 & 1 \\
\hline egyéb forrás & 4 & 1 & 1 \\
\hline
\end{tabular}

Forrás: saját kutatás

A járás agrártámogatásban részesülő családjainál, tehát kitüntetett szerepe van a gazdálkodásból, gazdaságból származó jövedelmeknek. Ezen belül az egységes földalapú támogatások jelentősége valamivel nagyobb, mint a mezőgazdaságból származó jövedelmeké (4. táblázat).

4. táblázat: A gazdaságból származó jövedelem megoszlása

\begin{tabular}{|c|c|c|c|c|}
\hline \multicolumn{2}{|c|}{$\begin{array}{c}\text { 4. táblázat: A gazdaságból származó jovedelem megoszlása } \\
\text { Forrás }\end{array}$} & van\% & $\mathbf{1 0 0 \%}$ & átlag\% \\
\hline egységes földalapú támogatás & 90 & 13 & 50 \\
\hline mezógazdasági tevékenység & 86 & 9 & 46 \\
\hline egyéb támogatás & 6 & 0 & 1 \\
\hline egyéb forrás & 4 & 0 & 1 \\
\hline egyéb kiegészító tevékenység & 1 & 0 & 0 \\
\hline
\end{tabular}

Forrás: saját kutatás

A válaszok összefüggéseit vizsgálva először is azt találtam, hogy hogy a mezőgazdaságból származó bevételek százalékos aránya függvényszerüen szorosan negatívan korrelál az egységes földalapú támogatásból származó bevételek százalékos arányával: r=-0,95. Másrészt a mezőgazdaságból származó bevételek százalékos aránya a gazdasági helyzetükkel elégedetlenkedő családokban alacsonyabb, mint az inkább elégedett családokban, míg az egységes földalapú támogatások százalékos arányait nézve pont fordított a helyzet $(\mathrm{t}=2,35$, $\mathrm{df}=286, \mathrm{p}=0,020$ illetve $\mathrm{t}=2,73, \mathrm{df}=286, \mathrm{p}=0,007$ ) (6. ábra). 


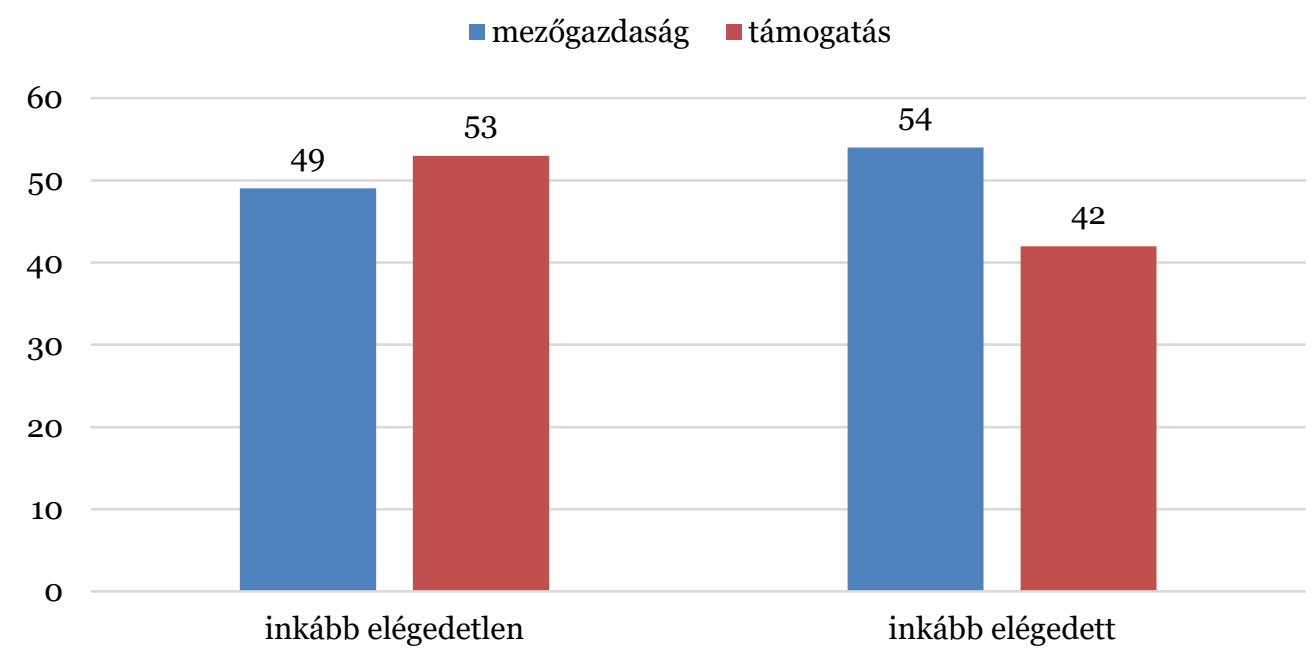

6. ábra: A mezőgazdaságból, illetve az egységes földalapú támogatásból származó jövedelmek Forrás: saját kutatás százalékos aránya a család anyagi helyzetének megítélése szerint

A leginkább figyelemre méltó eredmény azonban az, hogy a mezőgazdaságból származó jövedelem százalékos aránya azoknál a családoknál a legmagasabb, akik bővítési terveket dédelgetnek, míg az egységes földalapú támogatások százalékos aránya azok körében, akik csökkenteni tervezik a gazdaságukat. Az egységes földalapú támogatás, tehát segít enyhíteni a szegény családok helyzetén, de a mezőgazdasági termelést elsősorban azok tervezik bővíteni, akiknél eredményes ez a tevékenység, tehát az átlagosnál kisebb jelentősége van számukra a támogatásnak ( $\mathrm{F}=7,71 \mathrm{df}=2$ és 285, $\mathrm{p}=0,001$ illetve $\mathrm{F}=8,69, \mathrm{df}=2$ és 285, $\mathrm{p}=0,0005)$ (7. ábra).

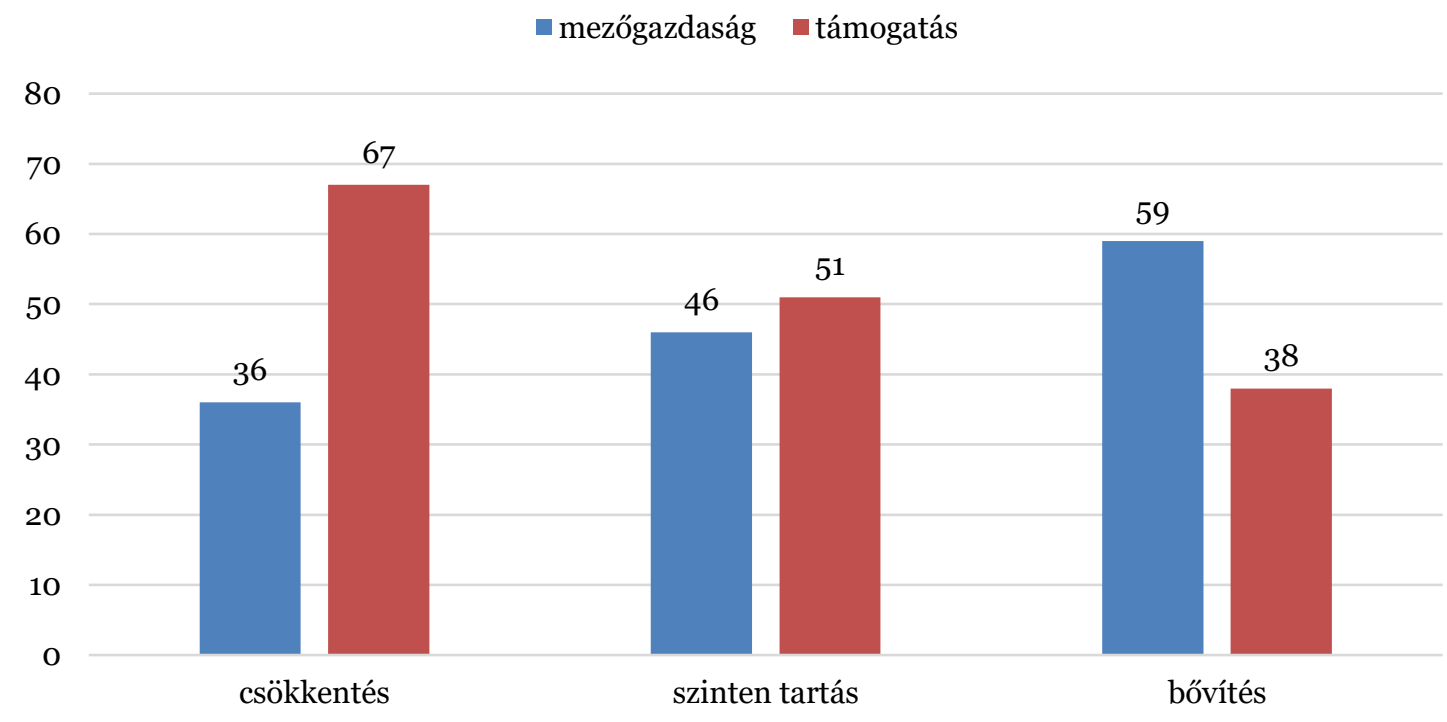

7. ábra: A mezőgazdasági tevékenységből, illetve az egységes földalapó támogatásból származó bevételek százalékos arányai, gazdasággal kapcsolatos tervek szerint Forrás: saját kutatás

\section{5. Összefoglalás}

Összefoglalásképpen megállapítható, hogy a kutatásban részvevő agrárvállalkozások felét 50 évnél idősebb férfi vezeti, tehát továbbra is felfedezhető az elöregedő agrártársadalom a térségben. Ugyanezen korosztály és a 60 évnél idősebbek dominanciája érvényesül a főfoglalkozások terén is. Ugyanakkor biztató jelenség, hogy a 18-29 évesek körében 42\% a diplomások aránya, azaz a vizsgált járásban is egyre több a diplomás agrárértelmiségi. 
Megállapítható továbbá az a tény, hogy a felsőfokú képzésben nem részesült gazdákat a rutin, a képzetteket viszont a tanulással szerzett tudás segíti hozzá az agrártámogatás elnyeréséhez. A járás támogatott gazdaságainak 69 százalékában a szinten tartás a gazdálkodási terv, ami hosszabb távon a gazdaságok zsugorodását eredményezheti. A szerényebb jövedelem egyáltalán nem ösztönzi növekedési tervek kovácsolására a járásban élő gazdákat, sőt inkább arra hajlamosítja őket, hogy feladják. Azonban az anyagi helyzettel való elégedettség, és a megtakarítások léte jelentősen növeli a bővítési tervek valószínüségét.

Figyelemre méltó eredmény, hogy a mezőgazdaságból származó jövedelem aránya azoknál a családoknál a legmagasabb, akiknek bővítési terveik vannak, míg az egységes földalapú támogatások aránya azok körében, akik csökkenteni tervezik a gazdaságukat. Az egységes földalapú támogatás, tehát segít enyhíteni az alacsonyabb jövedelmú családok helyzetén, de a mezőgazdasági termelést azok tervezik bővíteni, akiknél eredményes ez a tevékenység, tehát kisebb jelentősége van számukra a támogatásnak.

\section{Irodalomjegyzék}

[1] Hubai, J. (2006): Az uniós csatlakozás hatása Magyarország természetierőforrás-gazdálkodására. Nemzeti Tankönyvkiadó. Budapest. 176.

[2] Jávor, S., \& Jávor (2018): A.: A mezőgazdaság mint a vidékfejlesztés eszköze. In: A magyar tudomány napja a Délvidéken 2016. Szerk.: Szalma József, Dialóg Campus Kiadó, Budapest, 19-36.

[3] Kapronczai, I. \& Udovecz, G. (2009): A magyar agrárgazdaság helyzete. Gazdálkodás. 53. 6. 532-545.

[4] Ketskeméty, L. \& Izsó, L. (2005): Bevezetés az SPSS programrendszerbe. ELTE Eötvös Kiadó, Budapest, 459.

[5] Kovách, I. (2012): A vidék az ezredfordulón. A jelenkori magyar vidéki társadalom szerkezeti és hatalmi változásai. MTA Társadalomtudományi Kutatóközpont Szociológiai Intézet - Argumentum Kiadó, Budapest, 244 .

[6] KSH (2006): Magyarország mezőgazdasága, 2005. Gazdaságszerkezeti Összeírás. Előzetes adatok. Budapest. letöltés: https://www.ksh.hu/docs/hun/xftp/idoszaki/gszo/gszoo5.pdf

[7] KSH (2007): Gazdaságszerkezeti Összeírás. letöltés: https://www.ksh.hu/agrarcenzusok_gszo_2007

[8] Magda, S. (2008): Az agrárgazdaság és vidékfejlesztés az 1960-as évektől az EU csatlakozásig Magyarországon. Gazdálkodás. 21/52. 19-25.

[9] Nagy, G. (2012): A vidék helyzete hazánkban. Nem publikált egyetemi előadás. Debrecen 